\title{
The use of ventricular assist devices in pediatric patients with univentricular hearts
}

\author{
Christina J. VanderPluym, MD, Ivan M. Rebeyka, MD, FRCSC, David B. Ross, MD, FRCSC, and \\ Holger Buchholz, MD, Edmonton, Alberta, Canada
}

Improved survival outcomes for pediatric patients with ventricular assist devices (VADs) has expanded their application to complex univentricular cardiac lesions, including patients with systemic-to-pulmonary shunts, bidirectional cavopulmonary anastomoses (BCPAs), and total cavopulmonary Fontan circulations. Although it is generally recognized that complex cardiac anatomy is likely a significant risk factor affecting VAD survival, ${ }^{1,2}$ there remains a paucity of data examining the pediatric VAD experience with univentricular hearts.

\section{CLINICAL SUMMARY}

A 3-year-old $11.5-\mathrm{kg}$ boy with mitral valve atresia, hypoplastic left ventricle, coarctation, and transposition of the great vessels underwent an atrial septectomy with pulmonary artery banding followed by a BCPA. An extracardiac fenestrated Fontan procedure was performed at 3 years of age. Postoperatively, he had increasing diastolic dysfunction and thrombus formation in the extracardiac conduit necessitating emergency revision back to a BCPA with extracorporeal membrane oxygenation. A 30-mL Berlin Heart Excor Pediatric device was implanted with systemic right ventricular and aortic cannulation on postoperative day 10 . His post-VAD implantation course was complicated by a left subdural hemorrhage requiring decompressive craniotomy and evacuation on day 15 despite adherence to a standard anticoagulation protocol (the Edmonton anticoagulation protocol). On days 38, 89, and 111, fibrin collections in the outflow valve necessitated pump exchanges. The remainder of his VAD course was uneventful for bleeding or thromboembolic events. At 174 days after VAD implantation, he underwent successful transplantation and remains well with no neurological sequelae.

Ten pediatric patients with VADs with single-ventricle anatomy have been described in the literature since

From the Pediatric Ventricular Assist Device Program, University of Alberta and Stollery Children's Hospitals, Edmonton, Alberta, Canada.

Disclosures: Authors have nothing to disclose with regard to commercial support.

Received for publication Feb 8, 2010; revisions received June 17, 2010; accepted for publication June 28, 2010; available ahead of print Aug 9, 2010.

Address for reprints: Christina VanderPluym, MD, 4C2 WMC, Stollery Children's Hospital, 8440112 St. Edmonton, Alberta, T6G 2B7, Canada (E-mail: cjv1@ ualberta.ca).

J Thorac Cardiovasc Surg 2011;141:588-90

$0022-5223 / \$ 36.00$

Crown Copyright (C) 2011 Published by Elsevier Inc. on behalf of The American Association for Thoracic Surgery

doi:10.1016/j.jtcvs.2010.06.038
1987: 6 patients with Fontan circulations, 2 patients with BCPAs, and 2 patients with a systemic-to-pulmonary shunt (Table 1). ${ }^{3-12}$

\section{DISCUSSION}

The paucity of published reports on VAD support in patients with single-ventricle anatomy precludes firm recommendations regarding a preferred surgical technique and postoperative management strategy. However, clinical experience to date can be used to formulate suggestions based on the specific cardiac anatomy and physiology of the clinical scenario.

Patients with shunt-dependent circulation can be adequately supported with systemic ventricular inflow and aortic outflow cannulation. However, the parallel circulations usually require increased pump flow rates $(\geq 200 \mathrm{~mL}$. $\mathrm{kg}^{-1} \cdot \min ^{-1}$ ) to accommodate the need for both pulmonary and systemic perfusion and to maintain adequate oxygenation. Inadequate systemic oxygenation caused by impaired lung function can be addressed by placing a low-resistance oxygenator within the outflow circuit.

Patients with BCPAs, as in this case report, can be supported with a systemic ventricular inflow and aortic outflow cannulation technique. This management strategy has the potential advantage of maintaining systemic cardiac output in the presence of increased pulmonary vascular resistance at the expense of lower systemic oxygen saturations. For this reason, as with shunt-dependent circulation, a larger pump size might be needed to meet end-organ oxygen demand. BCPA physiology inherently unloads the hepatic, renal, and splanchnic circulations by reducing venous hypertension and thereby decreasing the risk of multiorgan failure.

The failing Fontan circulation poses several surgical options for VAD support that can be influenced by patient specific circumstances. Ventricular dysfunction as the primary cause for failing Fontan circulation can be addressed with single-pump VAD support of the systemic ventricle. However, increased pulmonary vascular resistance might require an additional pump within the pulmonary circulation to address systemic venous hypertension. In this situation implantation of a pulmonary VAD requires revision of the Fontan pathway for separation of the systemic venous and pulmonary circulations. Notwithstanding the extensive nature of the operation, there is an increased risk associated with the creation of a totally VAD-dependent pulmonary 
TABLE 1. Ventricular assist devices in pediatric patients with single-ventricle anatomy

\begin{tabular}{|c|c|c|c|c|c|c|c|c|}
\hline Case reports & $\begin{array}{l}\text { Age } \\
(y)\end{array}$ & $\begin{array}{c}\text { Weight } \\
(\mathrm{kg})\end{array}$ & Anatomy & $\begin{array}{c}\text { Surgical } \\
\text { procedure }\end{array}$ & Device & $\begin{array}{l}\text { Duration of } \\
\text { support (d) }\end{array}$ & Complication & Outcome \\
\hline \multirow[t]{2}{*}{$\begin{array}{l}\text { Matsuda } \\
\quad \text { et al, } 1988^{3}\end{array}$} & 10 & 16.0 & $\begin{array}{l}\text { Single- } \\
\text { ventricle } \\
\text { PS }\end{array}$ & Fontan & Toyobo & 7 & $\begin{array}{l}\text { MOF } \\
\quad \text { Cardiac tamponade } \\
\text { Re-exploration } \times 2\end{array}$ & Death day 7 \\
\hline & 3 & 10.0 & $\begin{array}{l}\text { Single- } \\
\text { ventricle } \\
\text { PS }\end{array}$ & $\begin{array}{l}\text { Systemic-to- } \\
\text { pulmonary } \\
\text { shunt (BT shunt) }\end{array}$ & Toyobo & 5 & Respiratory failure & Death day 5 \\
\hline $\begin{array}{l}\text { Sadeghi } \\
\quad \text { et al, } 2000^{4}\end{array}$ & 8 & 22.0 & $\begin{array}{r}\text { HLHS } \\
\text { MA }\end{array}$ & Fontan & BVS 5000 & 8 & $\begin{array}{l}\text { Pump change } \\
\text { for fibrin }\end{array}$ & Transplantation \\
\hline $\begin{array}{l}\text { Nathan } \\
\quad \text { et al, } 2006^{5}\end{array}$ & 4 & 12.0 & HLHS & Fontan & Berlin Heart & 28 & None & $\begin{array}{l}\text { Transplantation } \\
\text { Death caused by } \\
\text { graft failure }\end{array}$ \\
\hline Chu et al, $2007^{6}$ & 4 & 14.6 & HLHS & BCPA & Berlin Heart & 13 & $\begin{array}{l}\text { MOF } \\
\text { Bowel necrosis } \\
\text { Mesenteric, } \\
\text { hepatic, and renal } \\
\text { thrombi }\end{array}$ & Death day 13 \\
\hline $\begin{array}{l}\text { Calvaruso } \\
\text { et al, } 2007^{7}\end{array}$ & 10 & 32.0 & $\begin{array}{l}\text { Single RV } \\
\text { MA, PA }\end{array}$ & $\begin{array}{l}\text { Fontan } \\
\quad \text { (extracardiac } \\
\text { TCPC) }\end{array}$ & Berlin Heart & 7 & None & Transplantation \\
\hline Frazier et al, $2005^{8}$ & 14 & 63.0 & TA & Fontan & $\begin{array}{l}\text { Centrifugal pump } \\
\text { and HeartMate I }\end{array}$ & 45 & ARF, HIT & Transplantation \\
\hline Russo et al, $2008^{9}$ & & & HRHS & & & & & \\
\hline Pearse et al, $2009^{10}$ & 1.3 & NS & $\begin{array}{c}\text { DORV, MA } \\
\text { d-TGA }\end{array}$ & $\begin{array}{l}\text { Systemic-to- } \\
\text { pulmonary shunt }\end{array}$ & Berlin Heart & 49 & None & Transplantation \\
\hline $\begin{array}{l}\text { Cardarelli } \\
\quad \text { et al, } 2009^{11}\end{array}$ & 1.5 & NA & HLHS & $\begin{array}{l}\text { Fontan } \\
\quad \text { (extracardiac } \\
\quad \text { TCPC) }\end{array}$ & Berlin Heart & 179 & $\begin{array}{l}\text { Neuroimpairment } \\
\text { Change in pump } \\
\text { size }\end{array}$ & Decannulation \\
\hline Irving et al, $2009^{12}$ & 2.9 & 13 & HLHS & $\mathrm{BCPA}$ & Berlin Heart & 7 & None & Transplantation \\
\hline
\end{tabular}

PS, Pulmonary stenosis; $M O F$, multiorgan failure; $B T$, Blalock-Taussig; $H L H S$, hypoplastic left heart syndrome; $M A$, mitral atresia; $B C P A$, bidirectional cavopulmonary anastomoses; $R V$, right ventricle; $P A$, pulmonary artery; $T C P C$, total cavopulmonary; $T A$, tricuspid atresia; $H R H S$, hypoplastic right heart syndrome; $A R F$, acute renal failure; $H I T$, heparin-induced thrombocytopenia; $N A$, not applicable; $D O R V$, double-outlet right ventricle; $d$-TGA, transposition of the great arteries.

circulation. In the event of pump failure or a necessary pump change, complete cessation of pulmonary flow and cardiac output would occur.

For all types of palliated univentricular anatomy, strict adherence to anticoagulation protocols with frequent monitoring of the thromboelastogram, as opposed to reliance on activated clotting times, has improved the rate of thrombotic and hemorrhagic complications. ${ }^{13,14}$ Patients with singleventricle circulations are at increased risk of thromboembolic events caused by liver dysfunction and coagulation factor alterations, such as protein $\mathrm{C}$ deficiency. Vigilant surveillance of neurological status is pivotal.

Improvement in survival to transplantation has been demonstrated in recent years for all types of palliated singleventricle anatomy. This is likely attributable to refinement in patient selection, surgical technique, and anticoagulation management. Further experience and refinement of the preimplantation and postimplantation management is necessary to improve overall outcomes in this challenging group of patients.

\section{References}

1. Hetzer R, Loebe M, Potapov EV, Weng Y, Stiller B, Hennig E, et al. Circulatory support with pneumatic paracorporeal ventricular assist device in infants and children. Ann Thorac Surg. 1998;66:1498-506.

2. Blume E, Naftel D, Bastardi H, Duncan B, Kirklin J, Webber S. Outcomes of children bridged to heart transplantation with ventricular assist devices: a multiinstitutional study. Circulation. 2006;113:2313-9.

3. Matsuda H, Taenaka Y, Ohkubo N, Ohtani M, Nishigaki K, Ohtake S, et al. Use of a paracorporeal ventricular assist device for postoperative cardiogenic shock in two children with complex cardiac lesions. Artif Organs. 1988;12: 423-30.

4. Sadeghi A, Marelli D, Talamo M, Fazio D, Laks H. Short-term bridge to transplant using the BVS 5000 in a $22 \mathrm{~kg}$ child. Ann Thorac Surg. 2000; 70:2151-3.

5. Nathan M, Baird C, Fynn-Thompson F, Almond C, Thiagarajan R, Laussen P, et al. Successful implantation of a Berlin heart biventricular assist device in a failing single ventricle. J Thorac Cardiovasc Surg. 2006;131:1407-8.

6. Chu M, Sharma K, Tchervenkov C, Jutras L, Lavoie J, Shemie S, et al. Berlin heart ventricular assist device in a child with hypoplastic left heart syndrome. Ann Thorac Surg. 2007;83:1179-81.

7. Calvaruso D, Ocello S, Salviato N, Guardi D, Petrucelli D, Rubino A, et al. Implantation of a Berlin heart as single ventricle by-pass on Fontan circulation in univentricular heart failure. ASAIO J. 2007;53:e1-2.

8. Frazier OH, Gregoric I, Messner G. Total circulatory support with an LVAD in an adolescent with previous Fontan procedure. Tex Heart Inst J. 2005;32: 402-4. 
9. Russo P, Wheeler A, Russo J, Tobias JD. Use of a ventricular assist device as a bridge to transplantation in a patient with single ventricle physiology and total cavopulmonary anastomosis. Pediatr Anesth. 2008;18:320-4.

10. Pearse FB, Kirklin JK, Holman WL, Barrett CS, Romp RL, Lau YR. Successful cardiac transplant after Berlin Heart bridge in a single ventricle heart: use of aortopulmonary shunt as a supplementary source of pulmonary blood flow. J Thorac Cardiovasc Surg. 2009;137:e40-2.

11. Cardarelli M, Salim M, Love J, Simone S, Tumulty J, Conway D, Griffith B. Berlin heart as a bridge to recovery for a failing Fontan. Ann Thorac Surg. 2009;87:943-6
12. Irving CA, Cassidy JV, Kirk RC, Griselli M, Hasan A, Crossland DS. Successful bridge to transplant with the Berlin heart after cavopulmonary shunt. J Heart Lung Transplant. 2009;28:399-401.

13. Hetzer R, Alexi-Meskishvili V, Weng Y, Hubler M, Potapov E, Drews T, et al. Mechanical Cardiac support in the young with the Berlin Heart EXCOR Pulsatile Ventricular Assist Device: 15 years' experience. Semin Thorac Cardiovasc Surg Pediatr Card Surg Ann. 2006;9:99-108.

14. Potapov EV, Stiller B, Hetzer R. Ventricular assist devices in children: Current achievements and future perspectives. Pediatr Transplant. 2007;11: 241-55.

\title{
Pulmonary valve replacement in repaired tetralogy of Fallot by left thoracotomy avoid ascending aorta injury
}

\author{
Roland Henaine, MD, ${ }^{\mathrm{a}}$ Naoki Yoshimura, MD, ${ }^{\mathrm{b}}$ Sylvie Di Filippo, MD, PhD, ${ }^{\mathrm{a}}$ and Jean Ninet, MD, PhD, ${ }^{\mathrm{a}}$ \\ Lyon, France, and Toyama, Japan
}

We report the follow-up of a patient born with tetralogy of Fallot (TOF), which was corrected in childhood, who required when he was 28-years-old a pulmonary valve replacement (PVR) through a left anterolateral thoracotomy. This case demonstrates the advantages of this approach of simplicity and low risks of aortic lesions in particular.

\section{CLINICAL SUMMARY}

In the neonatal period, this male patient underwent a Blalock anastomosis through a left posterolateral thoracotomy. When the patient was 2 years old, a second systemic-pulmonary shunt through a right posterolateral thoracotomy was performed. The total repair was performed when the patient was 4 years old through a median sternotomy with extracorporeal circulation (ECC) and aortic clamping, with transannular enlargement of an hypoplastic pulmonary arterial trunk (PAT) with autologous pericardium. The outcome was quite favorable, with normal growth and without any functional symptoms, so medical monitoring was more deliberately spaced.

At the age of 28 years, during an ordinary medical checkup, the patient was asymptomatic. Furthermore, the Holter electrocardiogram showed sinus rhythm, a complete right

From the Department of Cardiac Surgery C, ${ }^{\text {a }}$ Cardiologic Hospital Louis Pradel, Lyon, France, and the First Department of Surgery, ${ }^{\mathrm{b}}$ University of Toyama, Graduate School of Medicine, Toyama, Japan.

Disclosures: Authors have nothing to disclose with regard to commercial support.

Received for publication May 13, 2010; revisions received June 18, 2010; accepted for publication June 28, 2010; available ahead of print Aug 5, 2010.

Address for reprints: Roland Henaine, MD, Department of Cardiac Surgery C, Cardiologic Hospital Louis Pradel, Avenue du Doyen Lépine, 69394 Lyon, France

(E-mail: roland.henaine@chu-lyon.fr).

J Thorac Cardiovasc Surg 2011;141:590-2

$0022-5223 / \$ 36.00$

Copyright (c) 2011 by The American Association for Thoracic Surgery doi:10.1016/j.jtcvs.2010.06.041 bundle branch block, and QRS prolonged to 0.2 seconds. Echocardiography showed significant pulmonary regurgitation with dilated hypokinetic right ventricle. A computed tomographic scan showed dilatation of the PAT to $55 \mathrm{~mm}$. Magnetic resonance imaging confirmed the infundibular dilatation, right ventricular ejection fraction of $25 \%$, and end-diastolic and end-systolic volumes of $172 \mathrm{~mL} / \mathrm{m}^{2}$ and $128 \mathrm{~mL} / \mathrm{m}^{2}$, respectively. The ascending aorta was dilated to $44 \mathrm{~mm}$ and completely adherent to the posterior of the sternum (Figure 1, $A$ ).

PVR was indicated. To avoid the sternotomy-associated risk of damage to the ascending aorta, the preferred route of left anterolateral thoracotomy was chosen, especially because the PAT was just subcostal (Figure 1, B).

With the patient under general anesthesia, left femorofemoral ECC was initiated. A left anterolateral thoracotomy was performed (Figure 2, A). After opening of the 4th intercostal space with preservation of the left internal thoracic artery, the pericardium was exposed after release of some of the lung adhesions. The PAT was easily exposed because it was decompressed under ECC. A longitudinal incision and resection of the pulmonary infundibular excess allowed good exposure of the pulmonary ring. A No. 25 Mitroflow bioprosthetic valve (Sorin SpA, Saluggia, Italy) was fixed with a 3-0 Prolene suture (Ethicon Inc, Somerville, NJ; Figure 2, B). Direct closure of the PAT, weaning from ECC, and closure of the thoracotomy were conventional.

The patient was transferred to the intensive care unit, extubated at 6 postoperative hours, and transferred to the cardiology department. Echocardiography showed a wellfunctioning bioprosthetic valve and absence of pericardial effusion. The patient returned to his home 8 days after the operation without functional symptoms. 